\title{
芯鉄骨合成柱材の耐震性能に関する解析的研究 ANALYTICAL STUDY ON SEISMIC PERFORMANCE OF CORE STEEL COMPOSITE COLUMNS
}

\author{
堺 純一*, 松井千秋**, 南 宏一*** \\ Junichi SAKAI, Chiaki MATSUI and Koichi MINAMI
}

\begin{abstract}
A numerical analysis for elastic-plastic behavior of core steel composite columns with considering buckling of main bars was carried out. In this paper it is shown that the results of the analysis agree with the experimental results, and the core steel composite columns under large axial force can hold axial load up to large deformation, but RC columns can not hold at last. Moreover, the effects of area and shape of cross section of core steel and axial force on the seismic performance of core steel composite columns are discussed.
\end{abstract}

Keywords: elastic-plastic behavior, buckling of main bars, axial force ratio, area of core steel, shape of core steel, anchor of core steel 弾塑性挙動，主筋の座屈，軸力比，芯鉄骨量，芯鉄骨断面形状，芯鉄骨の定着の有無

1 序

著者らは鉄筋コンクリート断面の中心に小さなせいの芯鉄骨を挿入 した合成柱材の耐震性能について調べており,一定軸力と繰返し水平 力を受ける芯鉄骨合成柱材の載荷実験を行い, 芯鉄骨合成柱材は高軸 カ下での鉄筋コンクリート（以下 RC）柱材の変形能力を大きく改善 できること, 内蔵鉄骨の圧縮耐力に対する柱の作用軸力の比が 1.5 程 度であれば芯鉄骨合成柱材は安定した挙動を示し, 大変形域において RC柱に見られるような軸力保持不能となる崩壊現象は見られないこ とを明らかにしだ．ささらに，建築構造骨組の柱梁接合部には芯鉄骨 を貫通させない工法を想定し，柱材端部で芯鉄骨が切れている合成柱 材の載荷実験を行った結果, 芯鉄骨端部のコンクリートが支圧破壊を 起こすため,その部分には横補強筋を密に配筋する必要があることを 示した2). 文献3）では芯鉄骨直下のコンクリートを横補强筋で拘束す ることにより支圧破壊を起こさない設計ができ，柱材端で芯鉄骨を 切った柱材は貫通させた柱材に比べ軸縮みの発散抑制の点で有利とな ることが報告されている.

$\mathrm{RC}$ 柱材は主筋の座届発生が急激な耐力劣化および軸力保持不能と なる崩壊につながるため, 主筋の座届歪の算定法および座屈しないた めの種々の設計式が提案されている4) -8). しかし, 座屈した後の柱材 の挙動に関する研究はほとんど無い.

* 九州大学大学院人間環境学研究院 助手 - 博士 (工学)

** 九州大学 名誉教授. 工博

*** 福山大学工学部建築学科 教授·工博
本論文では，一定軸力と繰返し水平力を受ける柱材について，主䇨 の座屈を考慮した柱材の弾塑性解析を行い,その解析結果が実験挙動 をよく追跡できることを示し, 芯鉄骨合成柱材の弾塑性挙動に及ほす 各種影響因子を考慮し，それらが柱材に及ほす影響を解析的に調べ， 芯鉄骨合成柱材の耐震性能について検討する。

\section{2 柱材の弾望性解析概要}

\section{1 解析方法と仮定}

柱材の弾塑性解析を行うために, 図1に示す解析モデルを用いた. 解析では弾塑性ヒンジ部のモーメント一曲率関係を算定することによ り，柱材に作用する水平力と部材角の関係を算定する。弾塑性ヒンジ 部のモーメント - 曲率関係の算定は断面を分割し, 平面保持に基づく 歪分布を仮定することにより応力分布を求め, 軸力が所定の軸力とな るまで収敛計算を行うことにより求めている.本解析では主筋の座屈 を考慮しているが, 芯鉄骨はコンパクト断面であること、コンクリー トが局部座屈を抑制することを考虑し，座届しないものとしている。

建築構造骨組の柱材端部での芯鉄骨の㨂入条件が柱材の挙動に及ほ す影響を考慮するために，a）芯鉄骨を連続材として㨂入し，柱梁接 合部内に貫通させた場合と，b）芯鉄骨を柱材にのみ挿入し，接合部 内には貫通させない場合を考慮した. 前者の芯鉄骨は柱頭, 柱脚部で

Research Assistant, Division of Architecture, Graduate School of Human-Environment Studies, Kyushu University, Dr. Eng. Prof. Emeritus, Kyushu University, Dr. Eng.

Prof., Dept. of Architecture, Faculty of Engineering, Fukuyama University, Dr. Eng. 


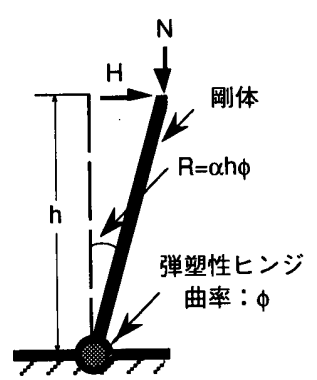

図 1 解析モデル

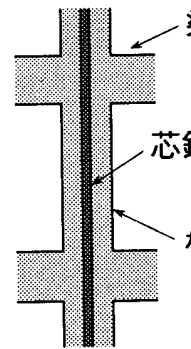

(a) 定着有り

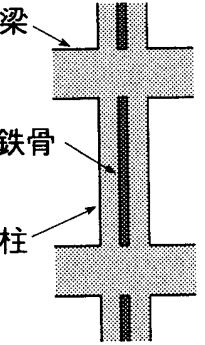

(b) 定着無

図 2 芯鉄骨端部での定着の有無
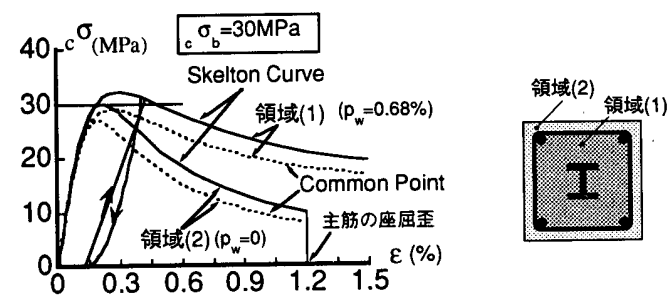

(a) コンクリートの応力 - 歪関倸

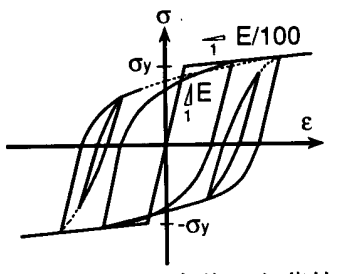

(b) 主筋㧍よび端部定着した芯鉄骨 図 3 材料の応力 - 歪関係

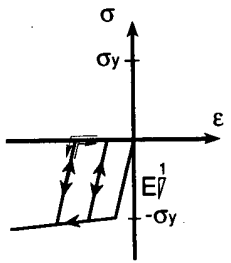

(c) 端部定着無しの芯鉄骨 モーメントと軸方向応力を接合部内の芯鉄骨に伝えることができると 云うことで, 芯鉄骨定着有りと称する.一方, 後者の芯鉄骨は材端部 の応力を接合部コンクリートの接触部分へ伝えることになり，芯鉄骨 断面内に引張応力が生じ得ないため,ここでは芯鉄骨定着無しと称す る.この場合, 平面保持の仮定に基づく断面内の圧縮応力分布に対す る圧縮軸力とモーメントは生ずるものとする.

材料の構成則は図3に示すモデルを用いた. コンクリートについて は図3(a)に示すように横補強筋で囲まれた部分とかぶりコンクリート 部分（横補強筋比 $\mathrm{p}_{\mathrm{w}}=0 ） に$ 分けており，骨格曲線に崎野·孫式9）を， 繰返し則に渡辺らのモデル10)を用いた．ただし，かぶりコンクリー トは主筋の座屈開始歪と等しい歪に達した時点以降は剥落したものと みなし圧縮力を負担できないものとしている.柱脚部で定着した芯鉄 骨および主筋には図3(b)に示す応力-歪関係を用いており，定着して いない芯鉄骨には鋼材に引張応力が生じず,バウシンガー効果に伴う 軟化現象はおきないものとし, 図 3 (c)に示す応力 - 歪関係を用いた.

\section{2 主筋の座屈開始䄳の算定}

主筋の座屈開始歪については中塚らの提案式6 8) を採用した。この 提案式では, 主筋の座屈歪に及ほす影響因子として, a) 横補強筋によ るコンクリートの拘束応力の分布性状の影響 (パラメー夕は横補強筋 のピッチとコンクリート断面せいの比), b) 平均拘束応力の影響 (パ ラメー夕は横補強筋比と横補强筋の降伏強度の積), c) 横補強筋の形 状および主筋位置の影響, d) コンクリート強度の影響, e) 横補強筋の 降伏強度の影響, が抽出され, 主筋の座屈開始歪が算定される。

\section{3 主筋の座屈後挙動の解析方法}

\subsection{1 解析仮定}

断面のモーメント - 曲率関係を断面区分法で求める上で，主筋が持

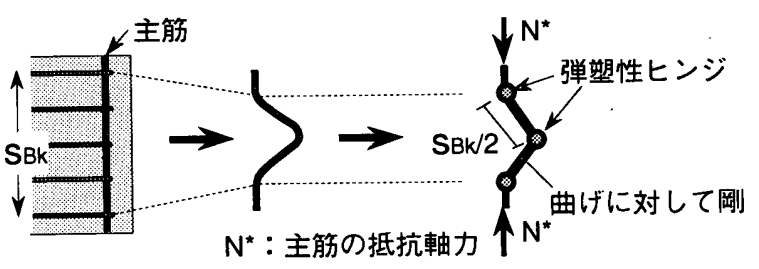

図 4 主筋の座屈後解析モデル
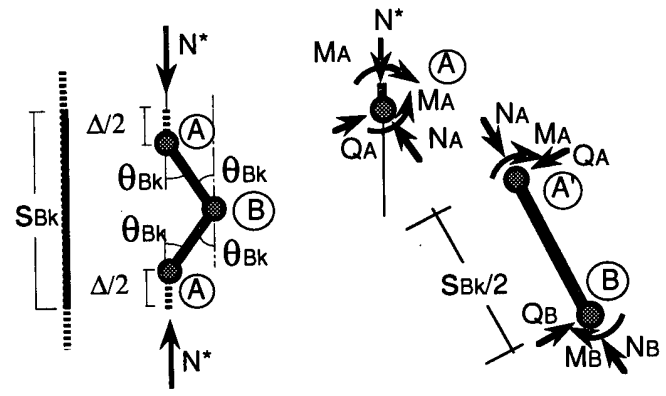

図 5 主筋の座屈後の変形と力の釣り合い

ちうる軸力 (図 4, 図 5 中の $N^{*}$ )を算定する. 主筋は座屈歪に達した時 点で主筋断面内に曲率が生じると考え，主筋断面を分割することによ り主筋の軸方向力 $\mathrm{N}^{*}$ とモーメントを以下の仮定の基で算定する.

1) 主筋が座屈した後は図4に示す機構モデルを考慮し, 弾塑性ヒン ジ部の回転により主筋が横にはらみだすものと考える.

2) 主筋が座屈した後も全断面の平面保持は保たれる。

3）主筋の構成則は座屈の前後共に図 3(b)のモデルを用いる.

4) 座屈区間長さ $\mathrm{s}_{\mathrm{Bk}}$ をコンクリート断面せい $\mathrm{cD}$ とする.

5) 座屈区間に存在する横補強筋はコンクリートの拘束に使われるも のと考え, 主筋が座屈したあとは, 横補強筋は降伏しているもの と見なし，座屈補剛には効果がないものとする.

6) 図 5 におけるA，B点の弾塑性ヒンジ部での回転角 $\theta_{\mathrm{Bk}}$ と曲率 $\phi_{\mathrm{Bk}}$ の間に(1)式が成り立つものとする。

$$
\theta_{B k}=\left(s_{B k} / 4\right) / 3 \cdot \phi_{B k}
$$

ここで, $\mathrm{s}_{\mathrm{Bk}}$ : 座屈区間長さである.

仮定 4）は以下のことを考慮している. 実験後の試験体の主筋の座 屈区間長さ $\mathrm{s}_{\mathrm{Bk}}$ は試験体により多少異なるが，ほとんど横補強筋間隔 $(5 \mathrm{~cm})$ の 2 倍〜3倍の長さである ${ }^{1), 2)}$. しかし，コンクリートが剥落し ている範囲が柱脚固定端からほほコンクリート断面せい $\mathrm{cD}(20 \mathrm{~cm})$ 上 がった範囲であることより，座屈区間長さ $\mathrm{s}_{\mathrm{Bk}}$ を $\mathrm{cD}$ とした，座屈区間 長さ $\mathrm{s}_{\mathrm{Bk}}$ を試験体の実験後の座屈長さよりも長くしたことにより, 本 解析結果は安全側の評価を与えることになる.

仮定6）は以下のことを考慮している．柱頭に横力が作用する材長 Lの片持柱の部材角は本来, 柱材の材長方向の曲率分布を積分するこ とにより得られるが (せん断変形はないものとする), 解析を簡略化 するために, 固定端に弾塑性ヒンジ部 (回転部) があり柱材長部分は 剛体とした解析モデルで考え, 弾塑性ヒンジ部の曲率 $\phi$ と部材角 $\theta$ の 間に（2）式が成り立つと仮定している．特に，弾性状態の部材端の 曲率とこのモデルの弾塑性ヒンジ部の曲率が一致するようにしてお り，弾塑性状態および軸力が作用する条件でも，材端固定端部の曲率 が部材の変形に対して大きく影響することを考慮し，この関係が成り 立つものと仮定した. 図5のA-B 間の中間点に反曲点があることを考 


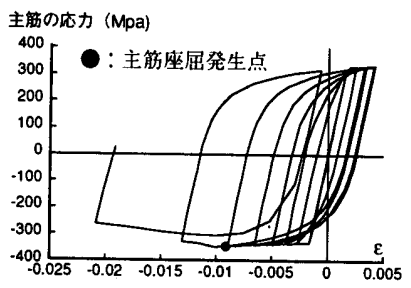

(a) 芯鉄骨合成柱材の主筋

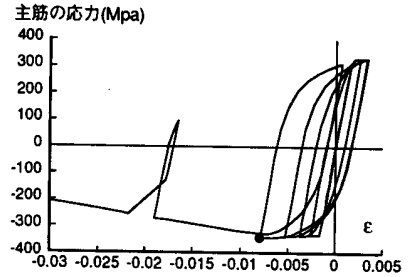

(b) RC 柱材の主筋
図 6 主筋の軸方向応力度と中心軸歪の計算例

慮すると，材長 $\mathrm{L}$ が $\mathrm{s}_{\mathrm{Bk}} / 4$ となることから(1)式が成り立つ。

$$
\theta=L / 3 \cdot \phi
$$

\subsection{2 変形の適合条件}

全断面の平面保持に基づく主筋断面の中心軸歪を $\varepsilon^{*}$ とする.

主筋が横にはらみ出すことによる鉛直方向の変形を $\Delta_{\mathrm{Bk}}$, 主筋の軸 方向歪による縮みを $\Delta_{\mathrm{c}}$ とすると, 変形の適合条件は(3)式, (4-1,2)式と なる，さらに，両式より主筋の中心軸歪は(5)式で与えられる。

$$
\begin{aligned}
& \Delta=\varepsilon^{*} \cdot s_{B k}=\Delta_{B k}+\Delta_{e} \\
& \varepsilon_{B k}=\Delta_{B k} / s_{B k}, \quad \varepsilon_{e}=\Delta_{e} / s_{B k} \\
& \varepsilon^{*}=\varepsilon_{B k}+\varepsilon_{e}
\end{aligned}
$$

ここで, $\Delta$ : 主筋の中心軸歪 $\varepsilon^{*}$ に対する主筋の縮み， $\varepsilon_{\mathrm{Bk}}$ : 主筋の 横へのはらみだしによる歪， $\varepsilon_{\mathrm{e}}$ : 主筋の軸方向力による歪,である. 図5の弾塑性ヒンジ部の回転角 $\theta_{\mathrm{Bk}}$ と $\varepsilon_{\mathrm{Bk}}$ には下式の関係が成立する.

$$
\begin{aligned}
& \varepsilon_{B k} \cdot s_{B k}=s_{B k} \cdot\left(1-\cos \theta_{B k}\right) \\
& \therefore \theta_{B k}=\cos ^{-1}\left(1-\varepsilon_{B k}\right)
\end{aligned}
$$

\subsection{3 主筋の座屈後の力の釣り合い}

図 5 中の A,B 各点での力の釣り合い条件は下式で表される.

$$
\begin{aligned}
& N_{A} \cdot \cos \theta_{B k}+Q_{A} \cdot \sin \theta_{B k}=N^{*} \\
& N_{A} \cdot \sin \theta_{B k}=Q_{A} \cdot \cos \theta_{B k} \\
& N_{B} \cdot \sin \theta_{B k}=Q_{B} \cdot \cos \theta_{B k} \\
& M_{A}+M_{B}-Q_{A} \cdot s_{B k} / 2=0
\end{aligned}
$$

ここで, $N_{A}, N_{B}: A, B$ 点における軸方向力, $Q_{A}, Q_{B}: A, B$ 点における せん断力, $M_{A}, M_{B}: A, B$ 点におけるモーメント, である.

図 5 中の $\mathrm{AB}$ 間の中間荷重が無いものとすると, 両点の断面に作用 する応力は同值となる。

\subsection{4 主筋の座屈後の軸力 $\mathrm{N}^{*}$ の計算例}

2.3.2, 2.3.3項で考慮した変形の適合条件および力の釣り合い条件を 用いることにより, 主筋の座屈後の軸力 $\mathrm{N}^{*}$ を数值解析で求めること ができる. 図6に断面解析を行った結果得られた主筋の挙動例を示す. 主筋の座屈発生後, 主筋は徐々に軸力が低下しており, 圧縮側への累 積歪が蓄積されていくことがわかる.

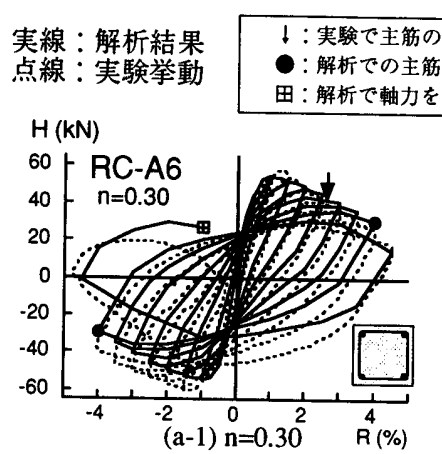

(a) RC 断面
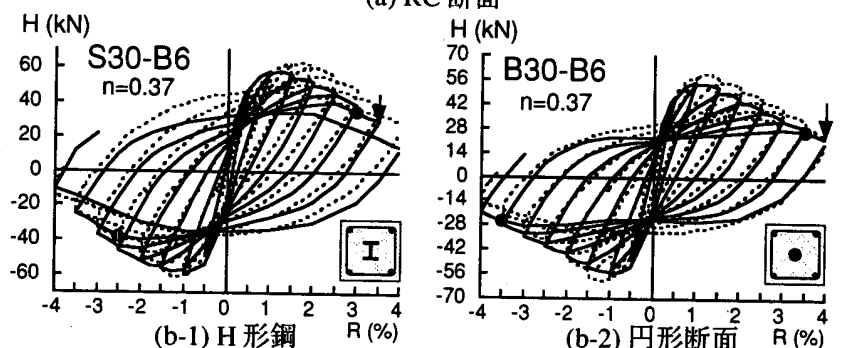

(b) 芯鉄骨合成断面

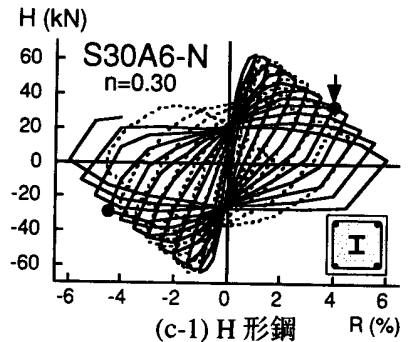

(c) 芯鉄骨合成断面（芯鉄骨柱脚定着無）

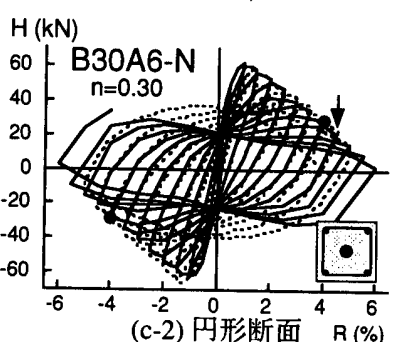

図 7 解析結果と実験挙動 1 .2)の比較

\section{4 解析結果と実験挙動の比較}

弾塑性解析で得られた弾塑性ヒンジ部におけるモーメント-曲率関 係を元に，一定軸力と繰返し水平力を受ける柱材の水平力-部材角関 係を図 1 に示すモデルを考慮し，下式により求める。（13）式の $\alpha は$ 弾塑性ヒンジ部の曲率と柱部材角を関係づけるもので, 鉄骨鉄筋コン クリート柱部材について検討した結果得られた（14）式を用いる ${ }^{111}$.

$$
\begin{aligned}
& H=M / h-N \cdot R \\
& R=\alpha \cdot h \cdot \phi \\
& \alpha=0.1+1.3 \cdot{ }_{c} D / h
\end{aligned}
$$

ここで, $\mathrm{H}$ :柱頭に作用する水平力, $\mathrm{M}$ :弾塑性ヒンジ部での抵抗モー メント, $\mathrm{N}$ :作用軸力, $\mathrm{R}$ :部材角, $\phi$ : 弾塑性ヒンジ部の断面曲率, $\mathrm{h}$ : 材長, $\mathrm{cD}:$ コンクリート断面, である.

解析の結果, 得られた挙動と実験挙動の比較の例を図7に示す. 図 中, 点線で実験挙動を, 実線で解析結果を示している. 解析で得られ た耐力はいずれの試験体も実験耐力を低く評価している.これは解析 では, 弾塑性ヒンジを柱脚固定端にあるとしていること, 実験では危 険断面が固定端よりも上に形成され高さが短くなることにより，見か け上，水平力 $\mathrm{H} て ゙$ 見たときの実験耐力が上昇するためと考えられる.

解析で得られた荷重・変形関係上の○印は主筋の座屈発生点を, 田 印は軸力を保持できず崩壊した点を示している，RC柱は主筋の座屈 
発生後, 軸力保持不能となり, 崩壊することが示されている（図7（a1,2)). 柱脚で芯鉄骨を定着した合成柱材は主筋の座屈後も, 耐力は低 下するものの, 軸力保持不能となる崩壊形とはならず, 安定した挙動 を示している (図7(b-1,2)). 本解析は主筋の座屈開始点および座屈発 生後の柱材の耐力の劣化性状を含め, 解析結果は実験挙動をよく追跡 できていると考えられる。なお, 柱脚で芯鉄骨を定着していない試験 体は，基礎梁部分が支圧破壊したため，実験耐力が急激に低下してい る.解析結果は基礎梁が支圧破壊するまでの実験挙動を追跡できてい ること (図 7(c-1,2)), 芯鉄骨下のコンクリートを充分拘束することに より支圧破壊を防ぐことができること妾，を考慮すると，大変形域で の弾塑性挙動を本解析で追跡できるものと考えられる.

\section{3 芯鉄骨合成柱材と鉄筋コンクリート柱材の弾塑性挙動}

\section{1 解析方法と解析変数}

高軸力下における芯鉄骨合成柱材の弾塑性挙動を把握し, RC 柱材 の挙動との違いを調べることを目的とし, 図8に示す断面の柱材に対 して弾塑性解析を行った， RC断面を共通とし，種々の芯鉄骨を挿入 した場合の挙動について検討を行っている.解析は一定軸力と繰返し 水平力を受ける曲げで耐力が決まる片持柱を想定している(せん断ス パン比 3). 文献 4 の指針式に依る RC 柱材のせん断信頼強度（終局限 界状態でのヒンジ領域の回転角 $\mathrm{Rp}=3 / 100 \mathrm{rad}$. で $1218 \mathrm{kN}$ ）および付着 破壊の影響を考慮したせん断信頼強度（Rp=3/100 rad. で $1230 \mathrm{kN} ） は$ 本解析に用いたRC柱材の各部材角における曲げ耐力よりも大きな值 となっている. 解析の載荷条件は, 部材角 $R=5 / 1000 \mathrm{rad}$. 単位とし, $\mathrm{R}=2.5 / 100 \mathrm{rad}$.まで正負交番で各变位振幅で2回繰り返す漸増変位振幅 で行い, 最大部材角 $3 / 100 \mathrm{rad}$. では 4 回の繰返し条件を与えている.

解析変数は, 芯鉄骨の断面形状抢よび量, 軸力比, 芯鉄骨の柱脚に おける定着の有無, 芯鉄骨の降伏強度, を選んだ.ただし, 芯鉄骨の 定着の有無の効果を見る上で芯鉄骨下のコンクリートは充分に補強筋 で拘束されているものとし支圧破壊は生じないものとする(芯鉄骨の 降伏強度 $\sigma_{\mathrm{y}}$ が325MPaなので芯鉄骨が圧縮で降伏するときの支圧強度 は，コンクリート圧縮強度 $\left({ }_{\mathrm{c}} \sigma_{\mathrm{b}}=30 \mathrm{MPa}\right)$ の 11 倍程度となる.さらに 歪硬化により鋼材の応力が上昇するが最終的にほとんど上昇しない). 芯鉄骨断面形状はH形鋼と正方形断面の2種類である. 芯鉄骨の量は, $\mathrm{RC}$ 断面積に対する鉄骨断面積の比 $\rho$ で表し，0.5, 1.0, 1.5, 2.0, 3.0， $5.0 \%$ の 6 種類とした. 軸力比 $\mathrm{n}$ は全断面圧縮耐力に対する作用軸力の 比とし, $0.1,0.2,0.3,0.35,0.4,0.45,0.5$ の 7 種類とした. 芯鉄骨の $\sigma_{y}$ は325MPa を標準とし(SN490), 高張力鋼として $\sigma_{\mathrm{s}} \sigma_{\mathrm{y}}$ が 700MPa の鋼材 を選んだ. 柱材の横補強筋はD13を $10 \mathrm{~cm}$ ピッチで配筋するものとし，
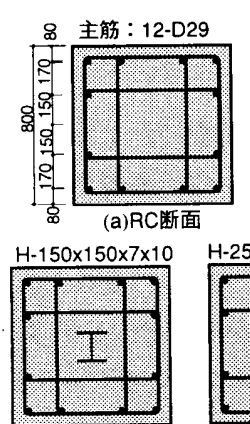

(b)鉄骨比 $0.5 \%$
[ 共通事項]

コンクリート断面：800 ×800 (mm) コンクリート生縮強度 : $30(\mathrm{MPa})$ 主筋 : 12-D29 (降伏強度 $\sigma_{\mathrm{y}}=345 \mathrm{MPa}$ ) 横補強筋： $p_{w}=0.64 \%: 4-D 13 @ 100 \mathrm{~mm} \quad\left(\sigma_{y}=345 \mathrm{MPa}\right)$ 芯鉄骨：降伏強度 $\sigma_{\mathrm{y}}=325 \mathrm{MPa}$ (高張力鋼: $700 \mathrm{MPa}$ )

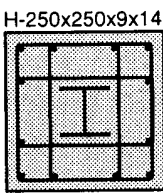

(c)鉄骨比 $1.5 \%$ 図 8 解析対象断面 (e)鉄骨比 $3.0 \%$

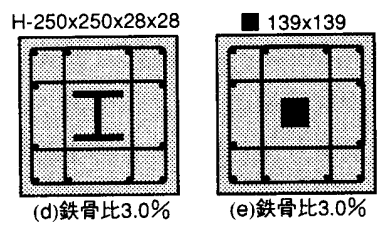

横補強筋比 $\mathrm{p}_{\mathrm{w}}$ は $0.64 \%$ (図 8 参照) であり，2.2 項で算定される主筋 の座屈開始歪は $1.20 \%$ となる。

\section{2 柱材の弾塑性挙動}

\subsection{1軸力比の違いが柱材の挙動に及ぼす影響}

軸力比 $\mathrm{n}$ を $0.3 ， 0.35,0.4,0.5$ としたときの柱材の水平力 - 部材角 関係を図9に示す. 図10(a),(b)に各除荷点における断面中心軸の歪挙 動を示している. 図9中の直線は, 柱脚部に塑性ヒンジが形成される としたときの塑性崩壊機構直線であり, 塑性ヒンジ部での曲げ酎力を 一般化累加強度で計算している. 実線は $0.85 \sigma_{\mathrm{c}} \sigma_{\mathrm{b}}\left({ }_{\mathrm{c}} \sigma_{\mathrm{b}}\right.$ : コンクリート強 度）と $\sigma_{\mathrm{y}}\left({ }_{\mathrm{s}} \sigma_{\mathrm{y}}\right.$ : 鋼材の降伏強度）を用いて計算した累加強度であり， 破線は $\sigma_{\mathrm{b}}$ と鋼材の $\sigma_{\mathrm{y}} \sigma_{\mathrm{y}}$ で計算したものである. 図 9 中, ○点は主筋が 座屈した時点を示し,田印は軸力を保持できず崩壊した時点を表して いる. 軸力比 $\mathrm{n}$ が 0.3 以下では, $\mathrm{RC}$ 柱材，芯鉄骨合成柱材ともに主筋 の座屈が生じることなく安定した挙動を示す. $\mathrm{n}=0.35$ では部材角が $3 /$ $100 \mathrm{rad} . て ゙ R C$ 柱材抢よび芯鉄骨合成柱材で主筋が座屈することにより 耐力が減少しているが, 本解析の載荷条件では最終的に RC 柱, 芯鉄 骨合成柱ともに軸力保持不能となる崩壊現象は生じていない. $\mathrm{n} \geqq 0.4$ では RC 柱材は主筋が座屈した後, 軸力を保持できず崩壊するのに対 し，柱断面積に対する芯鉄骨断面積の比が $0.5 \%$ と小量の鉄骨が挿入 されておけば, 合成柱材は主筋が座屈し耐力が低下するものの, 水平 力が無くなるまで軸力を保持できている（図9(a) と(b)の比較).

\subsection{2芯鉄骨量の違いが柱材の挙動に及ぼす影響}

$\mathrm{n} \geqq 0.4$ の高軸力を受ける場合, 小量の芯鉄骨を挿入することで合成 柱材は RC 柱材に比べ主筋の座屈時期を遅らせることができ, 変形能 力, エネルギー消費能力を大きくすることが可能である.ささらに芯鉄 骨量を増加させることにより，柱材の最大耐力発揮後の酎力の劣化勾 配を軽減でき, 変形能力を大きくすることが可能であることがわかる (図9の(b),(c) と(d)の比較).

芯鉄骨合成柱材は, RC 柱材が軸力保持不能となる中心軸歪以上の 歪にも耐えることができ, 芯鉄骨量を増すことにより中心軸歪の発散 も抑えられていることがわかる(図 $10(a-3,4))$.

芯鉄骨合成柱材が安定した挙動を示すための芯鉄骨量と芯鉄骨の圧 縮耐力に対する最大作用軸力の比の関係を図11に示す.安定した挙動 を示す条件として（15）式を満たすこととした（図9中，(15）式を満 足する柱材には*印を付している).

$$
M_{R 2} \geq 0.9 \cdot M_{\max }
$$

ここで, $\mathrm{M}_{\mathrm{R} 2}$ : 部材角 $\mathrm{R}=2 / 100 \mathrm{rad}$. での正側の 3 回目の繰返し載荷時 の柱脚部のモーメント, $\mathrm{M}_{\text {max }}$ : 最大抵抗モーメントである.

この条件を満たす $\mathrm{RC}$ 柱材および合成柱材は部材角 $\mathrm{R}=3 / 100 \mathrm{rad}$. で の 2 回の繰返し載荷に対して耐力は最大耐力の $80 \%$ を保持している. 同部材角での 4 回の繰返しでは最大耐力の約 $70 \%$ まで低下している が, 軸力保持不能となる不安定現象は生じていない. 文献4では勒性 限界点を最大耐力の $80 \%$ の耐力時の変形と定義しているが,この定義

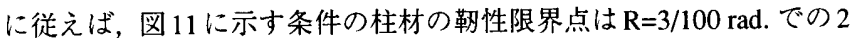
回の繰返し載荷時点に対応していることになる.

\subsection{3芯鉄骨の断面形状の違いが柱材の挙動に及ぼす影響}

コンパクト断面である正方形断面を芯鉄骨とした合成柱材の水平 力 - 部材角挙動を図 $9(\mathrm{e})$ に示す（鉄骨比 $3 \%)$. 内蔵鉄骨にH 形鋼を用 
$\mathrm{n}=\mathrm{N} / \mathrm{srcNu}, \quad \mathrm{nc}=\mathrm{N} / \mathrm{cNu}, \quad \mathrm{ns}=\mathrm{N} / \mathrm{sNu}, \quad \mathrm{n}_{1}=\mathrm{srcN}_{1} / \mathrm{srcNu}$ $\mathrm{cNu}=\mathrm{bD} \cdot{ }_{\mathrm{c}} \sigma_{\mathrm{b}}, \mathrm{sNu}={ }_{\mathrm{s}} \mathrm{A} \cdot{ }_{\mathrm{s}} \sigma_{\mathrm{y}}$

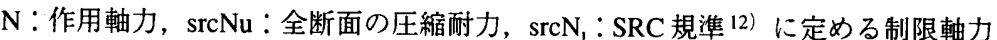
$\mathrm{b}, \mathrm{D}$ : コンクリート断面の幅とせい, sA：芯鉄骨断面積

${ }_{c} \sigma_{\mathrm{b}}$ : コンクリートの圧縮強度, ${ }_{\mathrm{s}} \sigma_{\mathrm{y}}$ : 芯鉄骨の降伏強度

\section{$\mathrm{n}=0.30$}

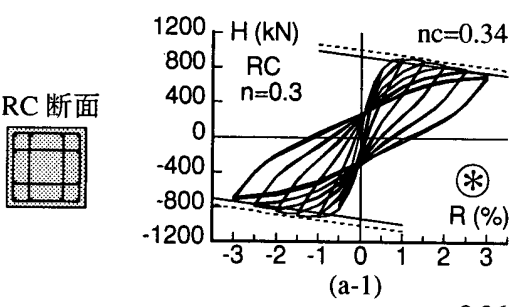

鉄骨比 $0.5 \% \quad 800\left[\begin{array}{lr}1200 \\ \text { H }(\mathrm{kN})\end{array}\right.$

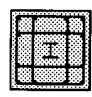

$n_{1}=0.31$

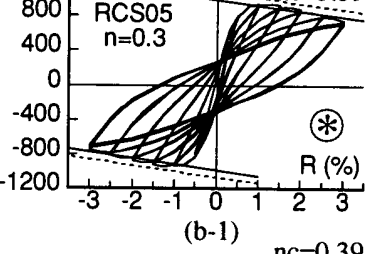

$1200 \mathrm{H}(\mathrm{kN}) \quad \mathrm{nc}=0.39$

鉄骨比 $1.5 \%$ 800 - RCS15

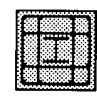

$n_{1}=0.34$

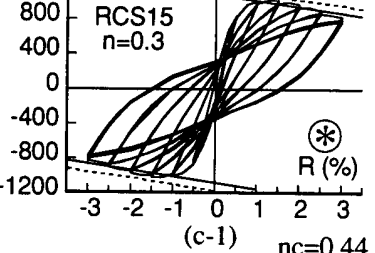

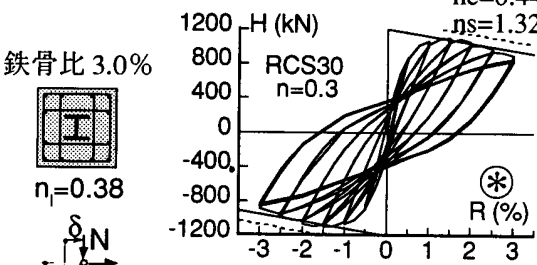

(d-1)
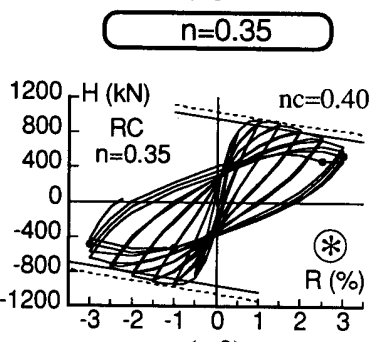

(a-2)

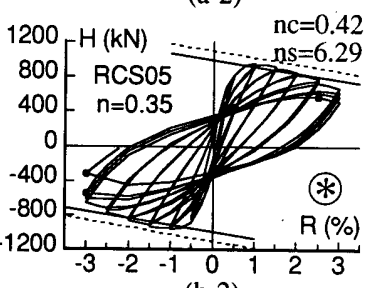

(b-2) $\mathrm{nc}=0.45$
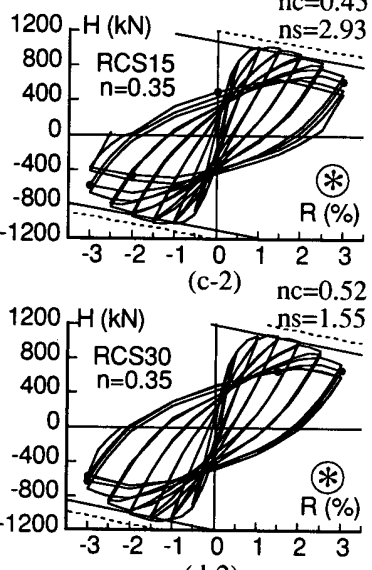

(d-2) $\mathrm{n}=0.40$

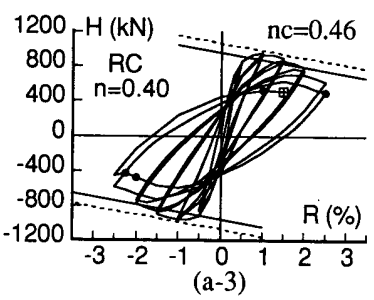

$1200, \mathrm{H}(\mathrm{kN}) \quad \ldots \quad \mathrm{nc}=0.48$

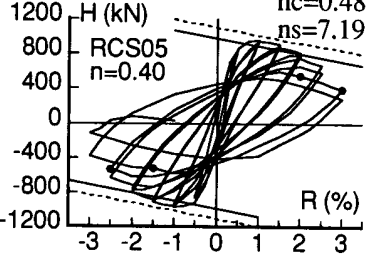

(b-3)
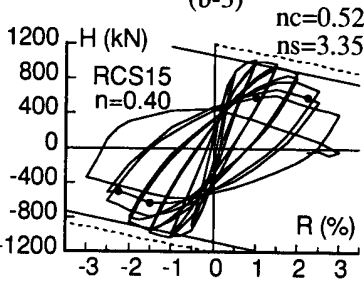

(c-3) $\mathrm{nc}=0.59$

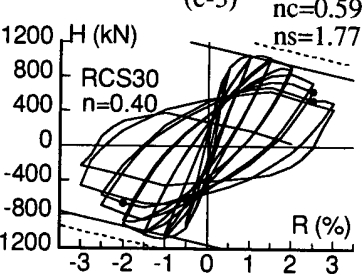

$(\mathrm{d}-3)$

(i) 芯鉄骨の有無および鉄骨量の違いが柱材の挙動に及ほすす影響

芯鉄骨

芯鉄骨：

断面

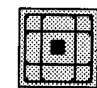

鉄骨比 $3.0 \%$ $n_{1}=0.38$
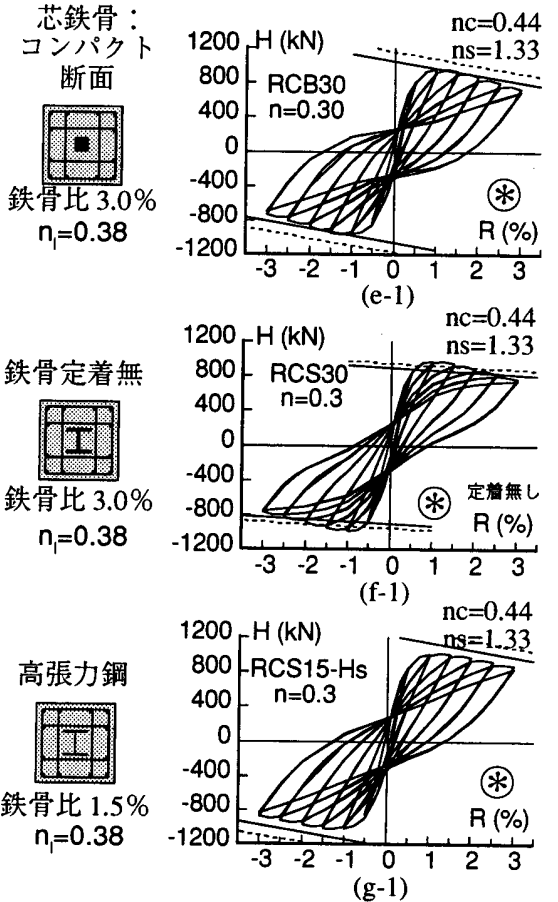
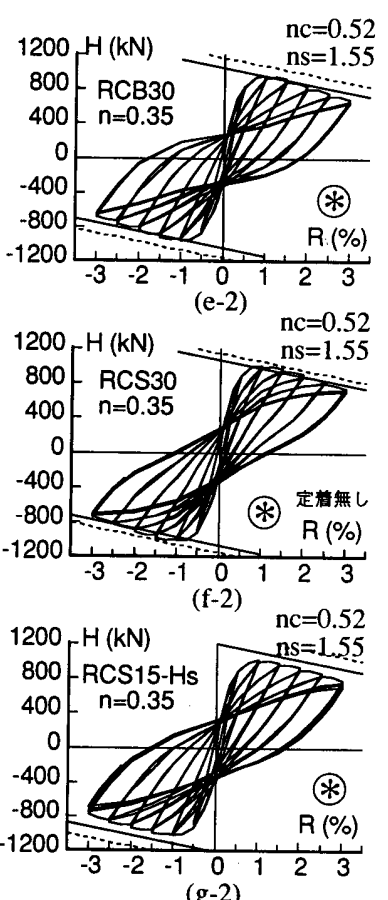
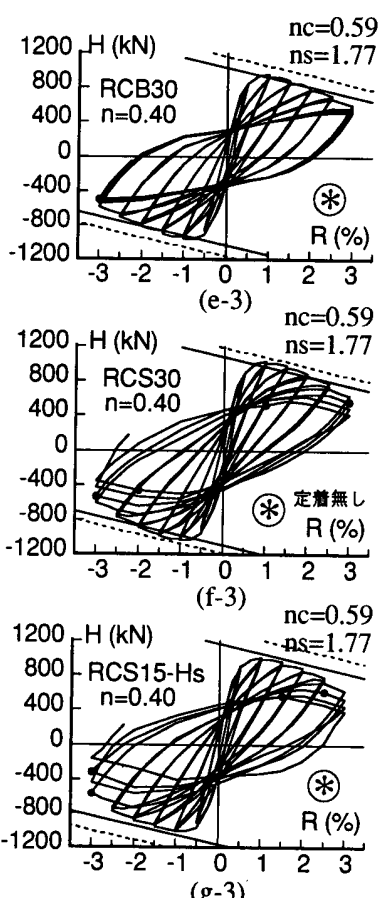

$\mathrm{n}=0.50$
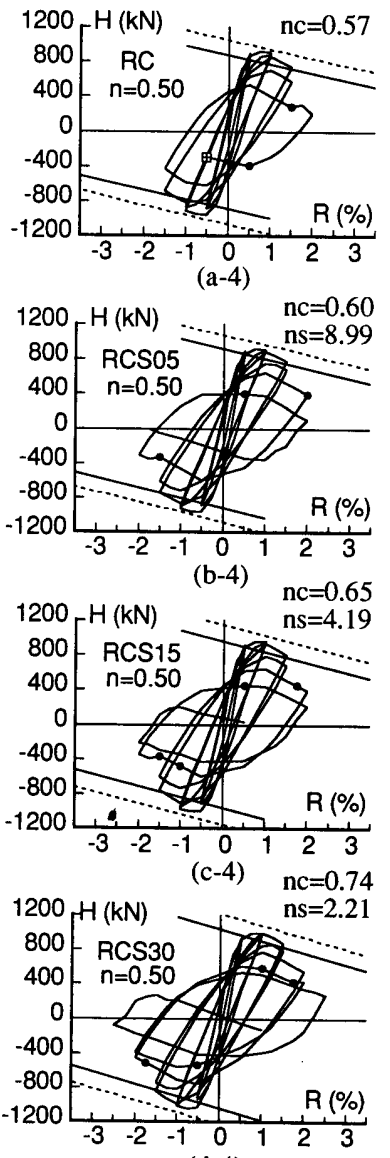

(d-4)
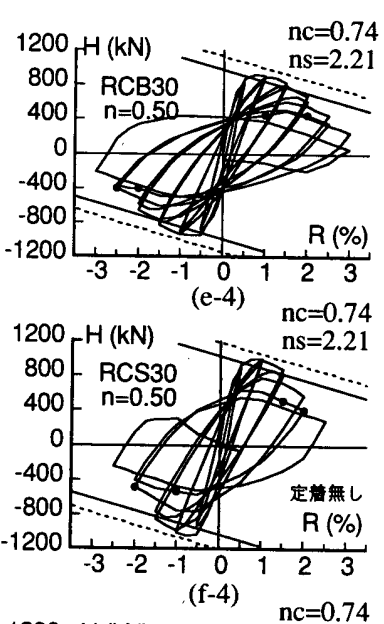

$1200 \mathrm{H}(\mathrm{kN})-\ldots . \mathrm{ns}=2.21$

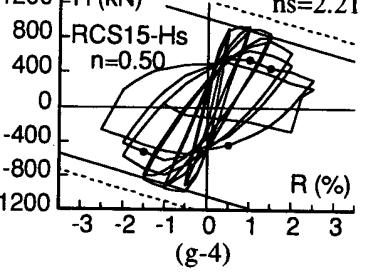

：主筋が座屈した時点

田：軸力を保持できず崩壊した時点

$\circledast ：(15)$ 式の条件を満たす柱材

(ii) 芯鉄骨の条件の違いが芯鉄骨合成柱材の挙動に及ほす影響

図 9 柱材の弾塑性挙動の解析結果 


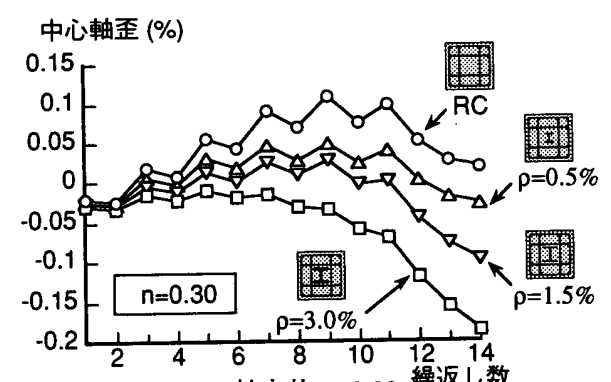

(a-1) 軸力比 $\mathrm{n}=0.30$ 繰返し数
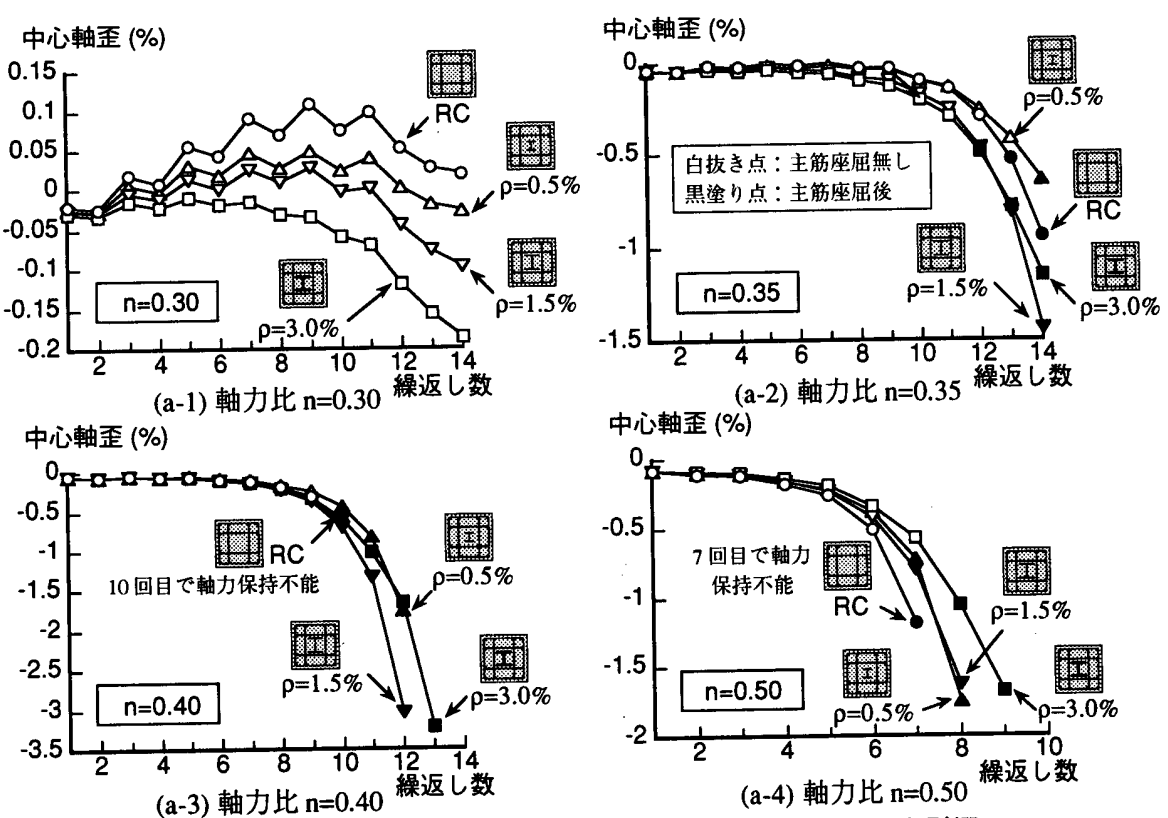

(i) 芯鉄骨の有無および芯鉄骨量の違いが中心軸歪挙動に及ほす影響

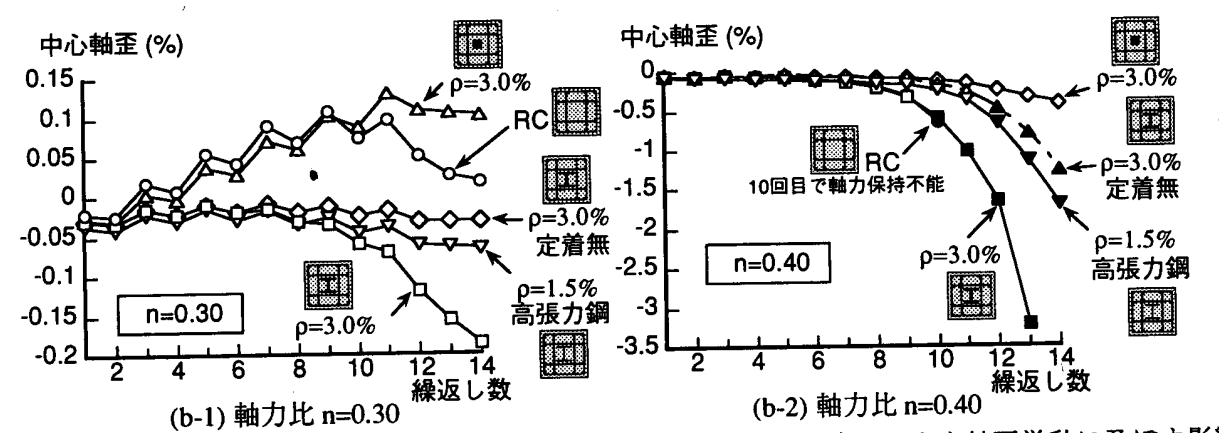

(ii) 芯鉄骨の条件の違いが中心軸歪挙動に及はす影響

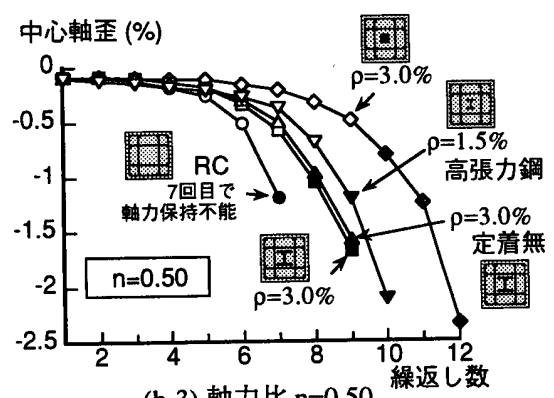

(b-3) 軸力比 $n=0.50$

図 10 断面の中心軸歪の挙動

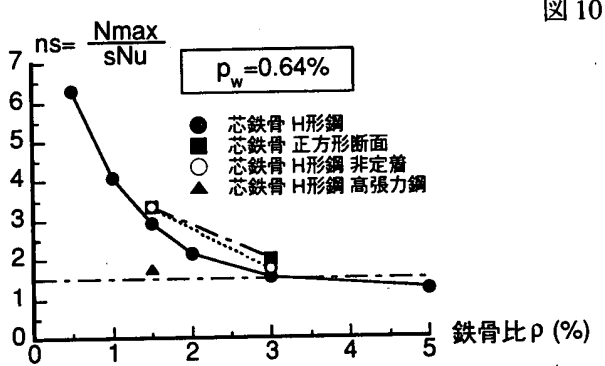

図 11 芯鉄骨圧縮耐力に対する最大作用軸力の比（15 式）

いた場合に比べ，曲げ耐力は小さくなるが，最大耐力発揮後の耐力劣 化現象が低く抑えられ（図9(d)と(e)の比較), 中心軸歪の発散が抑え られていること (図 10(b-1,2,3)) より, 芯鉄骨としてコンパクトな断 面を用いた方が芯鉄骨の効果が有効に発揮されることがかかる.

\subsection{4 芯鉄骨の定着の有無が柱材の挙動に及ぼす影䭗}

柱脚部で芯鉄骨の定着を切った柱材 (芯鉄骨はH形断面)の水平力部材角関係を図9(f)に示す. 図中の塑性崩壊機構直線は, 芯鉄骨の引 張强度を 0 として計算した一般化累加強度で求めている. 軸力比nが $0.35 \sim 0.4$ 程度では, 芯鉄骨を定着していない柱材は定着した柱材に 比へ，最大耐力発揮後の耐力の低下率が低く抑えられ（図9の(d-2,3) と(f-2,3)の比較), 中心軸歪の発散も抑えられている(図10(b-2)).こ れは鉄骨を定着した柱材に比べ鉄骨が曲げに殆ど抵抗せず，圧縮力に 抵抗できるためである。しかし $\mathrm{n}=0.5$ 程度では定着の有無の影響は殆 どない（図9の(d-4)と(f-4)の比較㧍よび図 10(b-3))。コンパクトな芯
鉄骨断面を用いた場合, 定着した柱材でも芯鉄骨断面内にはほとんど 引張応力が生じないため, 鉄骨の定着の有無による影響は殆どない。 3.2.5鋼材の降伏強度の違いが柱材の挙動に及ほす影響

芯鉄骨に高張力銅を用いた柱材の挙動を図 $9(\mathrm{~g})$ に示している。断面 は芯鉄骨の鉄骨比を $1.5 \%$, 降伏強度を $700 \mathrm{MPa} と し て お り ，$ 鉄骨比が $3.0 \%$ て降伏強度が325MPaの鋼材を内蔵した断面の圧縮耐力と一致さ せてある．高張力鎆を用いた場合， $\mathrm{n} \leqq 0.35$ では最大耐力は龬材の降 伏強度とコンクリート强度を 0.85 倍した強度で計算した一般化累加強 度に達しない (各軸力比に打ける(解析耐力/累加強度)のうち最小 となる值は 0.93$)$ が, 水平力-部材角関保において, 軸力比が 0.4 およ び 0.5 程度の高軸力下での最大耐力発揮後の劣化勾配は鎆材に SN 490 銅を用いた柱材に比べ抑えられている(図9の(d-3,4)と(g-3,4)の比較). 中心軸歪も高張力銅を用いた方が発散が抑えられている（図 $10(\mathrm{~b}-1$, 2,3)）これは銅材の降伏歪が大きいこと，および断面を小さくできる ことにより，芯鉄骨が曲げに対する抵抗よりも軸力に対する抵抗が大 きく現れるためである.

4 芯鉄骨挿入による鉄筋コンクリート柱材の耐震性能の捕強効果 柱材が最終段階までに消費したエネルギーを図12に示す.縦軸は同 じ軸力比でC柱材が消費したエネルギーで除して無次元化している. 軸力比nが 0.35 以下では本解析の繰返し条件下では柱は最終的に崩 


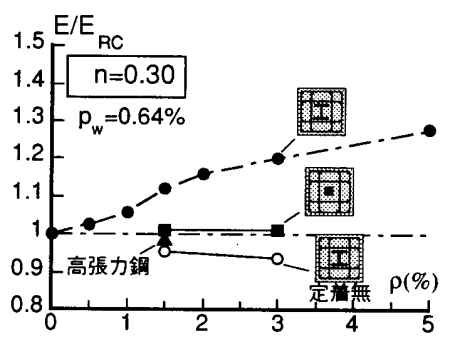

(a) $\mathrm{n}=0.30$

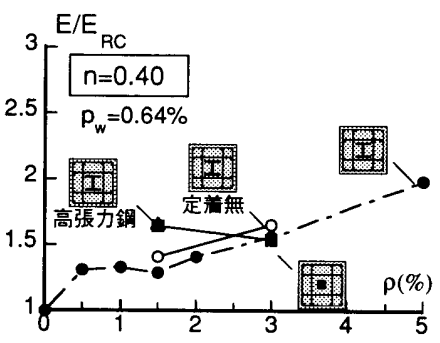

(b) $\mathrm{n}=0.40$

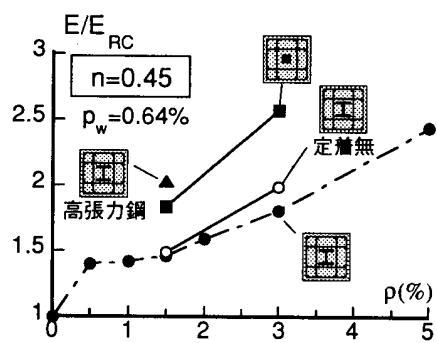

(c) $n=0.45$

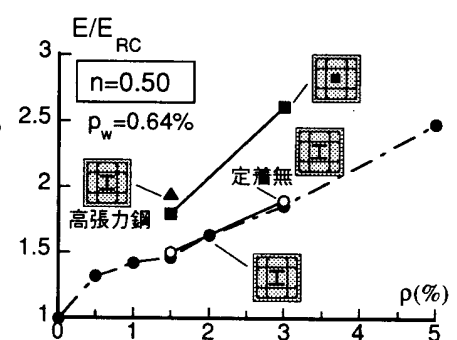

(d) $\mathrm{n}=0.50$

図 12 柱材が消費したエネルギー

壊せず，芯鉄骨を挿入しても $\mathrm{RC}$ 柱材の消費エネルギーとさほど違い は無く, 芯鉄骨による補強の必要性はない.しかし, 軸力比 $\mathrm{n} か ゙ 0.4$ 以 上の高軸力となると,コンクリート断面積に対する鉄骨断面積の比が $0.5 \%$ 程度の芯鉄骨を挿入した合成断面でも RC柱の耐震性能を向上さ せることができ，さらに芯鉄骨量を増やすことによりその効果が大き くなることがわかる.

コンパクトな芯鉄骨断面を用いた合成柱材は, 軸力比 $\mathrm{n}$ が 0.45 程度 以上の高軸力下においては消費エネルギーの点で他の柱材に比べ最も

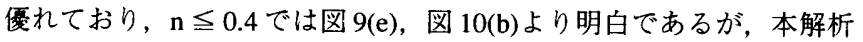
の繰返し条件のもとでは柱材の損傷が他の柱材に比べ少ないことより (このために図12に示している消費エネルギーが小さい),このような 合成断面が耐震性能の点で優れていることがわかる.

\section{5 結論}

一定軸力と繰返し水平力を受ける, 芯鉄骨合成柱材および鉄筋コン クリート（RC）柱材の弾塑性解析を行った結果, 以下の知見を得た.

1）主筋の座屈現象を考慮し弾塑性解析を行った結果，解析結果は芯 鉄骨合成柱材および RC 柱材の実験挙動を良く追跡できる.

2）全断面圧縮耐力に対する作用軸力の比が 0.4 程度以上となる RC 柱 材 $\left(\mathrm{p}_{\mathrm{w}}=0.64 \%\right)$ は主筋の座屈が生じることにより急激に耐力が低 下し，軸力を保持できず崩壊する，芯鉄骨合成柱材は，主筋が座 屈することにより曲げ耐力が低下するものの, 最終段階で水平力 が無くなるまで軸力を保持できることを解析的に示した。

3）芯鉄骨の圧縮耐力に対する作用軸力の比nsを図11に示す値程度と することにより，芯鉄骨合成柱材は安定した挙動を示す。

4）芯鉄骨としてコンパクトな断面を用いた方が, H形鋼を用いた場合 よりも優れた耐震性能を有している．これは芯鉄骨が殆ど曲げに 効かず, 軸方向力に効くためであり，その結果，H形䤡を用いた場 合に比べ，断面中心軸歪の進行が抑えられるからである.

5）芯鉄骨の定着の有無による柱材の耐震性能はほぼ同様であると考 えられるが, 芯鉄骨端部の定着を切った場合, 高軸力下において, 断面中心軸の圧縮歪の発散抑制に対して有効に㗢き，全断面圧縮 耐力に対する作用軸力の比が 0.4 程度では, 芯鉄骨を定着した場合 に比べ，変形能力が大きくなる。

6）高張力鎆を芯鉄骨として使用した場合，普通鋼に比べ最大耐力発 揮後の抵抗モーメントの低下率および断面の中心軸の圧縮歪の発 散を抑える効果がある。

7） RC. 柱材の崩壊を防ぐ方法として, 横補強筋を密に配筋する補強 法, 柱断面を鋼管で巻く補強法が報告されているが, これらの補 強法はコンクリートの拘束効果に期待するものであり，有効な補 強法であると考えられる，本論文で述べた芯鉄骨合成柱材は，芯
鉄骨を内蔵させることにより，コンクリートの圧縮歪の進展を抑 制し，主筋の座屈を遅延させる効果に期待するものである，さら に高軸力下におかれた柱材のコンクリートの損傷が著しくても， 芯鉄骨が作用軸力に対し充分に内蔵されておけば，建築構造骨組 の落階につながる柱材の軸力保持不能となる崩壊形は阻止でき， 柱材の耐震性能の向上に有効な補強法の一つであることを示した. 本論文では曲げで部材耐力が決まる柱材を対称としたが，せん断 で耐力が決まる柱材に挿入した場合には，芯鉄骨がコンクリート を分断することになりRC部分のせん断耐力を低下させることにな るが, 柱全体の挙動で考えると芯鉄骨のダボ効果によりコンク リートの脆性的なせん断破壊が阻止されることになり，変形能力 に優れた柱材にできるものと考えられる。

\section{謝辞}

本研究は平成9-10年度文部省科学研究費 (奨励研究(A)09750664, 代 表：堺 純一)の助成を受けて行った.ここに記して感謝いたします.

\section{参考文献}

1）堺 純一,松井千秋,南 㕕一,平川葉子：芯鉄骨合成柱の耐震性能に関する 実験的研究, 日本建築学会構造系論文集,第 526 号,pp.201-208, 1999.12。

2）堺 純一、松井千秋,南 宏一, 平川葉子：芯鉄骨を挿入した RC柱部材の弾 塑性挙動に関する実験的研究, コンクリート工学年次論文報告集, Vol.21, No.3, 1999.7.

3）爱河知紀,平田定男,八木大児,中西貞夫,南 宏一：芯鉄骨で補強した RC 柱 の耐震性能に関する一考察, 日本建築学会構造工学論文集, Vol. 46B, pp.241$252,2000.3$.

4）日本建築学会：鉄筋コンクリート造建物の䩚性保証型酎震設訃指針·同解説 , 1997.7.

5）加藤大介：鉄筋コンクリート部材の主筋の座屈性状に関する研究, 日本建築 学会構造系論文報告集, 第 436 号, pp.135-143, 1992.6.

6）中塚 佶,中川裕史,阪井由尚：単軸圧縮応力を受けるコンファインドコンク リート内に配筋された圧縮軸筋の座屈におよほすす諸要因の影響, 一コンファ インドコンクリート内に配筋された圧縮軸筋の座屈に関する研究（その1）, 日本建築学会構造系論文集, 第 497 号, pp.141-148, 1997.7 .

7）中塚 佶,前川元伸,中川裕史：単軸単調圧樎荷重下における軸筋の座屈時ひ ずみ推定式, -コンファインドコンクリート内に配筋された圧縮軸筋の座屈に 関する研究 (その2) -, 日本建築学会構造系論文集, 第 516 号, pp.145-149, 1999.2.

8）斉藤 格,中塚 佶,前川元伸,中川裕史,溝口 茂: コンファインドコンク リート内に配筋された圧縮軸筋の座屈時ひずみ（その2) 圧縮・引張繰り返 し載荷時における軸筋の座屈時ひずみに及ぼす諸要因の影響, 日本建築学会 学術講演梗概集, 構造 IV, pp.301-302, 1998.9.

9）崎野健治,棌玉平：直線型横補強材により拘束されたコンクリートの応力歪み関係, 日本建築学会構造系論文集, 第 461 号, pp.95-104, 1994.7.

10) 鎌田圭次郎, 大住和正, 渡辺史夫, 六車 熙: 各種強度の鉄筋混使用による RC 断面曲け性能の制御, 日本建築学会大会学術講演梗概集, pp.505-506, 1991.9.

11) 堺 純一, 松井千秋：鉄骨鉄筋コンクリート柱部材の復元力特性に関する研 究-単一H形銅を内蔵したSRC柱の骨格曲線の定式化-, 日本建築学会構造系 論文集，第 534 号,pp.183-190, 2000.8

12）日本建築学会：鉄骨鉄筋コンクリート構造計算規準・同解説, 1987.6. 